\title{
On Schizophrenia and New Generation Drugs
}

Meltzer presents an informative review of antipsychotic drug action and serotonin (Meltzer 1999). However, his conclusion that new generation drugs with serotonin antagonism are efficacious for the primary negative symptoms of schizophrenia contrasts with our view (Carpenter 1995; Carpenter et al. 1995) and merits further consideration.

It is important to distinguish primary, or diseasebased, negative symptoms from negative symptoms secondary to other sources (e.g., depressive anhedonia, neuroleptic akinesia, paranoid social withdrawal, sedative anergia) (Carpenter et al. 1998, 1993). The clinical trials cited by Meltzer (1999) do not make this distinction. Other studies have addressed primary negative symptoms by design and fail to support the efficacy hypothesis for clozapine (Buchanan et al. 1998; Conley et al. 1994; Rosenheck et al. 1999). A meta-analysis of these and other studies reaches similar conclusions (Wahlbeck et al. 1999). The view that new generation medications are not a therapeutic answer for trait negative symptoms of schizophrenia is further reinforced in the six-month controlled study in outpatients where neither haloperidol nor clozapine was associated with negative symptom improvement (Schooler et al. 1999), and in studies by Lieberman et al. (1994) and Tandon et al. (1993) where improvement appeared to be accounted for by secondary negative symptoms. Conley et al. (1998) also failed to observe negative symptom improvement with olanzapine. It is important to note that superior efficacy for psychosis was shown in each of the clozapine studies, so the lack of efficacy for negative symptoms was not a non-responsive cohort effect.

Meltzer suggests a direct effect on primary negative symptoms with risperidone and olanzapine, but this is based on path analysis where some, but not all, sources of variance are in the model (Moller et al. 1995; Tollefson and Sanger 1997). The hypothesized direct effect in these studies is based upon the statistical term "unexplained variance." There are two problems with the assumption that unexplained variance is due to a direct therapeutic effect: 1) a reasonably thorough list of the causes of secondary negative symptoms has not been included in these equations; and 2) there are many sources of "noise" in a clinical trial which contribute to unexplained variance.

The distinction between primary and secondary negative symptoms has theoretical and practical importance (Carpenter et al. 1993, 1999). We believe that as yet there is no proven treatment for the avolitional pathology described by Kraepelin (1971), and serotonin antagonism is not a promising lead. More interesting are results from study designs which isolate trait or deficit negative symptoms, and suggest a role for glutamatergic mechanisms in achieving a negative symptom response independent of an antipsychotic response (Goff et al. 1995, 1999; Heresco-Levy et al. 1996, 1999; Javitt et al. 1994). Observations in a d-serine trial also appear supportive, but negative symptom improvement coincided with improvement in psychosis, and the primary/secondary issue is not resolved (Tsai et al. 1998).

William T. Carpenter, Jr., M.D. Robert Conley, M.D. Brian Kirkpatrick, M.D. University of Maryland School of Medicine Maryland Psychiatric Research Center Baltimore, Maryland

\section{REFERENCES}

Buchanan RW, Breier A, Kirkpatrick B, Ball P, Carpenter WT Jr (1998): Positive and negative symptom response to clozapine in schizophrenic patients with and without the deficit syndrome. Am J Psychiatry 155(6):751-60

Carpenter WT (1995): Serotonin-dopamine antagonists and treatment of negative symptoms. J Clin Psychopharmacol 15(Suppl 1):30S-35S

Carpenter WT, Arango C, Buchanan RW, Kirkpatrick B (1999): Deficit psychopathology and a paradigm shift in schizophrenia research. Biol Psychiatry 46:352-360

Carpenter WT, Buchanan, RW, Kirkpatrick B, Tamminga C, Wood F (1993): Strong inference, theory testing, and the neuroanatomy of schizophrenia. Arch Gen Psychiatry $50: 825-831$

Carpenter WT, Conley RR, Buchanan RW, Breier A, Tam- 
minga CA (1995): Patient response and resource management: Another view of clozapine treatment of schizophrenia. Am J Psychiatry 152:827-832

Carpenter WT, Heinrichs DW, Wagman AMI (1988): Deficit and non-deficit forms of schizophrenia: The concept. Am J Psychiatry 145:578-583

Conley R, Richardson C, Kent D, Gounaris C, Zaremba S (1994): Clozapine responses varies in deficit vs. nondeficit schizophrenic subjects. Biol Psychiatry 35(9):746

Conley RR, Tamminga CA, Bartko JJ, Richardson C, Peszke M, Lingle J, Hegerty J, Love R, Gounaris C, Zaremba S (1998): Olanzapine compared with chlorpromazine in treatment-resistant schizophrenia. Am J Psychiatry 155(7):914-920

Goff DC, Tsai G, Levitt J, Amico E, Manoach D, Schoenfeld DA, Hayden DL, McCarley R, Coyle JT (1999): A placebo-controlled trial of D-cycloserine added to conventional neuroleptics in patients with schizophrenia. Arch Gen Psychiatry 56:21-27

Goff DC, Tsai G, Manoach DS, Coyle JT (1995): Dose-finding trial of d-cycloserine added to neuroleptics for negative symptoms in schizophrenia. Am J Psychiatry 152:12131215

Heresco-Levy U, Javitt DC, Ermilov M, Mordel C, Horowitz A, Kelly D (1996): Double-blind, placebo-controlled, crossover trial of glycine adjuvant therapy for treatment-resistant schizophrenia. Br J Psychiatry 169:610 617

Heresco-Levy U, Javitt DC, Ermilov M, Mordel C, Siliop G, Lichenstein M (1999): Efficacy of high-dose glycine in the treatment of enduring negative symptoms of schizophrenia. Arch Gen Psychiatry 56:29-36

Javitt DC, Zylberman I, Zukin SR, Heresco-Levy U, Lindenmayer J-P (1994): Amelioration of negative symptoms in schizophrenia by glycine. Am J Psychiatry 151:12341236

Kraepelin E (1971): Dementia Praecox and Paraphrenia. New York, Robert E Krieger
Lieberman JA, Safferman AZ, Pollack S, Szymanski S, Johns C, Howard A, Kronig M, Bookstein P, Kane JM (1994): Clinical effects of clozapine in chronic schizophrenia: Response to treatment and predictors of outcome. Am J Psychiatry 151(12):1744-1752

Meltzer HY (1999): The role of serotonin in antipsychotic drug action. Neuropsychopharmacology 21(25):106S-115S

Moller HJ, Muller H, Borison RL, Schooler NR, Chouinard G (1995): A path-analytical approach to differentiate between direct and indirect drug effects on negative symptoms in schizophrenic patients. A re-evaluation of the North American risperidone study. Eur Arch Psychiatry Clin Neurosci 245(1):45-49

Rosenheck R, Dunn L, Peszke M, Cramer J, Xu W, Thomas J, Charney D (1999): Impact of clozapine on negative symptoms and on the deficit syndrome in refractory schizophrenia. Department of Veterans Affairs Cooperative Study Group on Clozapine in Refractory Schizophrenia. Am J Psychiatry 156(1):88-93

Schooler N, Marder S, Kane J, Chengappa KNR, Wirshing W, Umbricht D, Parepally H, Wirshing D, Petrides G (1999): Clozapine and risperidone: A 29-week randomized clinical trial. Schizophr Res 36(1-3):296

Tandon R, Goldman R, DeQuardo JR, Goldman M, Perez M, Jibson M (1993): Positive and negative symptoms covary during clozapine treatment in schizophrenia. J Psychiatric Res 27:341-347

Tollefson GD, Sanger TM (1997): Negative symptoms: A path analytic approach to a double-blind, placebo- and haloperidol-controlled clinical trial with olanzapine. Am J Psychiatry 154(4):466-474

Tsai G, Yang P, Chung L-C, Lange N, Coyle JT (1998): D-serine added to antipsychotics for the treatment of schizophrenia. Biol Psychiatry 44:1081-1089

Wahlbeck K, Cheine M, Essali A, Adams C (1999): Evidence of clozapine's effectiveness in schizophrenia: A systematic review and meta-analysis of randomized trials. Am J Psychiatry 156(7):990-999 